\title{
Illustrating Human Behavior Theories in Social Work Using HBO's The Wire
}

\author{
Jocelyn DeVance Taliaferro ${ }^{1^{*}}$, MSW, PhD, Lucy A. Lawrence ${ }^{2}$, MSW, PhD \\ $I^{*}$ Associate Professor, School of Social Work, North Carolina State University, Raleigh, NC 27695, United States. \\ ${ }^{2}$ Professor, Department of Social Work, Warren Wilson College, Swannanoa, NC, United States.
}

Article Details
Article Type: Review Article
Received date: $23^{\text {rd }}$ December, 2020
Accepted date: $22^{\text {nd }}$ January, 2021
Published date: $25^{\text {th }}$ January, 2021
"Corresponding Author: Jocelyn DeVance Taliaferro, School of Social Work, North Carolina State University, Raleigh, NC
27695, United States. E-mail: Jocelyn_Taliaferro@ncsu.edu
Citation: Taliaferro, J.D.V. and Lawrenceb, L.A. (2021). Illustrating Human Behavior Theories in Social Work Using HBO's
The Wire. J Ment Health Soc Behav 3(1):130. https://doi.org/10.33790/jmhsb1100130
Copyright: 02021 , This is an open-access article distributed under the terms of the Creative Commons Attribution License
4.0, which permits unrestricted use, distribution, and reproduction in any medium, provided the original author and source are
credited.

\section{Abstract}

Human Behavior in the Social Environment theories are a crux of social work education. However, they are often difficult to discuss in class because theories can be abstract and elusive for students. This may be especially true when exploring macro level theories. Social work students are attracted to the field of social work because of its practical application and often because they are interested in working with micro level systems. Further, in considering social work education at the BSW and often MSW level, using Bloom's Taxonomy, theory discussions and synthesis are certainly beyond the undergraduate expectation and similarly difficult for MSW students to contextualize. However, HBSE theories are the conceptual foundation of competent social work practice. This lack of exposure can also be said of working with diverse populations. Many undergraduate BSW programs are not in urban areas, but social workers need to understand urban problems as they advocate for social policy development and work with urban client systems at various levels of practice. As such the authors of this paper have created a context for elucidating macro HBSE theories exposing students to realistic urban scenarios using HBO's The Wire. This framework provides both explanations of common SW macro level theories and discusses the ways in which a contemporary television show can be used in class to annotate macro theories including Systems Theory, Symbolic Interactionism, Social Construction, Conflict Theory, and Rational Choice Theory.

Keywords: Social Work Theory, Teaching Using The Wire,

\section{Introduction}

The purpose of the social work profession is to promote human well-being for individuals and communities. According to its accreditation body, the Council on Social Work Education (CSWE) [1] Social Work is "guided by a person and environment construct, a global perspective, respect for human diversity, and knowledge based on scientific inquiry. [Its purpose] is actualized through its quest for social and economic justice, the prevention of conditions that limit human rights, the elimination of poverty, and the enhancement of the quality of life for all persons, locally and globally." (p5). Social Work has a mission to serve those in disenfranchised and marginalized communities, and challenge systems of oppression and injustice.

Often those accessing social work services live in urban areas. According to recent data, $80 \%$ of the United States population resides in cities (Washington Post, 2018) and it is anticipated the percentage will increase to $89 \%$ by 2050 [2]. The Pew Research Center [3] identifies social welfare issues in urban centers as including substance dependency and addiction, limited affordable housing, unequal access to health and mental health services, crime, and availability of employment. Many social work students are limited in their understanding of the vagaries of these grand challenges [4]. However, they are tasked with responding to the symptoms and consequences of many of these problems. Providing this care from an acontextual point of view leaves social work students with a blind spot in their ability to address the issues that are presented when working with individuals, families, organizations, in communities. It is imperative that social workers recognize the urban milieu to be able to respond to these issues in urban settings.

Since the urban experience is not a monolith, it is important that students, even those from urban areas, are exposed to multidimensional urban experiences. The client systems that students will eventually serve will have been shaped by their respective context. Therefore, it is important that students are exposed to these myriad environments. To practice effectively, social work students must have an understanding of human behavior in the social environment (HBSE).

\section{Literature Review}

Human Behavior in the Social Environment (HBSE) and the CSWE Core Competencies

Social work education emphasizes the reciprocity between humans and their physical/social/cultural/economic environments. As the environment influences the behavior and adaptations of the humans who populate it, so human behavior has an impact on the contexts in which human interaction takes place [5]. Theoretical foundations of human behavior in the social environment (HBSE) provide praxis by which social work students and practitioners apply concepts and constructs to understand patterns of interactions and relationships [6]. At the micro level, HBSE focuses on human development throughout the life course. At the macro level, political, social, ecological, and cultural environments encompass HBSE content.

Social work education is competency-based with an outcomesoriented approach to curriculum design to ensure students can demonstrate the integration and application of competencies in practice [1]. Social work education programs at the bachelor's and master's levels are required to prepare students for mastery of nine core competencies as set forth by the Council on Social Work Education (CSWE) Education and Policy Accreditation Standards (EPAS). Each social work competency describes the skills, knowledge, and cognitive and affective processes required at the generalist level of practice. Each competency has a set of behaviors that integrate these observable components of the competencies or 
Through HBSE courses, students gain competencies such as engaging/intervening/evaluating practice with individuals, groups, families, organizations, and communities; advancing human rights and social, economic, and environmental justice; and engaging diversity and difference in practice. This content is particularly important because an understanding of human behavior provides insight on responses to interventions and practice models. Understanding HBSE is helpful for the development of multidimensional practice methods. It provides a context for designing, implementing, and evaluating social work interventions. Specifically, systems theory, ecological systems theory, symbolic interactionism, social construction, conflict theory, and rational choice, theories have been identified as dominant theories in social work that aid in the development of responses to human problems [7]. We contend that HBO's The Wire provides a unique opportunity to explore HBSE and its attendant theories via popular culture media.

\section{HBO's The Wire and HBSE}

The Wire is a critically acclaimed HBO series that serves as a portrait of urban life. It is a microcosm of contemporary problems and purported solutions set in the specific context of Baltimore, Maryland. The multi-season television series can be used as the case study for an exploration of crime, drugs, economic bifurcation, politics, education, and the media [8,9]. Using The Wire as a backdrop, we will examine the portrayals of the urban experience and the attendant social problems of life in an economically depressed or struggling major metropolitan area by illuminating predominantly macro, and cognitive theoretical perspectives of human behavior in the social environment. Theoretical frameworks will be presented using examples from The Wire which will be used to elucidate the framework.

Although the series premiered in 2002 and ended in 2008 after five successful seasons, as a pedagogical tool, The Wire has maintained strength and relevance. While under-acclaimed during its run on HBO, subsequently there has been much more interest in the show as a classroom tool due to the show's refusal to exploit typical urban stereotypes [9]. It has recently been noted that younger audiences have "rediscovered" The Wire during the Spring 2020 quarantine when many households indulged in binge-watching iconic television shows during COVID-19 stay-at-home orders [10].
The concepts of police brutality, urban unrest, political posturing, gentrification, and economic bifurcation and decline remain timely and germane. Institutions such as Harvard, Duke, Marist, NC State, and Warren Wilson College use The Wire as a social document $[8,11$, 12] to elucidate broad concepts such as race and class [13], crime [14], and representations of public education [15] through examination of the complex lives of characters challenged individually and collectively by their urban environment. While there are several resources in the form of books and articles that discuss the use of the series in teaching myriad subjects, we will add to the discourse by providing insight on how to engage students with theories of human behavior used in the social work classroom to examine current issues that have come to light through the social unrest over police brutality and racial inequities across the United States.

It is anticipated that in any college level classroom, additional resources, including newspaper and journal articles, film, and textbooks will be used to complement the television episodes. It is also assumed that instructors for whom this article is written have some familiarity with The Wire. It is not feasible or advisable that we provide the story lines of the series in describing the examples. The series is much too rich and complex to provide detailed descriptions for audiences unfamiliar with the series. Further, we acknowledge that to use the entire series to teach has its challenges, one of which being that the series is 60 hours of television [8]. However, it is completely relevant and encouraged that instructors use a flipped classroom format to use a portion of the series (i.e., individual episodes or seasons) to demonstrate the theory under discussion.

It is here that we caution that this article does not give instructions on how to teach The Wire. That is not the intent of this article. Instead it illuminates theories of human behavior using The Wire as a contextual marker for students. It can be used as a blueprint for instructors who want to use The Wire to teach HBSE content. Because most citizens are not and cannot be exposed to the complexity of social problems in an intimate way, the HBO series The Wire will be used as the "fishbowl" in which students can get this exposure. For ease of navigating this article and a summary of the theories and their examples, Table 1 provides a detail of the theories highlighted, a brief definition, and an example including the season referenced.

\begin{tabular}{|l|l|l|}
\hline Theory & Definition & Example/Season \\
\hline Systems Theory & $\begin{array}{l}\text { States that human behavior is influenced by } \\
\text { multiple factors that impact overall functioning } \\
\text { and wellbeing. These systems work to create or } \\
\text { maintain homeostasis. Addressing problematic } \\
\text { subsystems can increase functioning and } \\
\text { positively impact behavior. }\end{array}$ & $\begin{array}{l}\text { All Five Seasons: The Barksdale Drug } \\
\text { Season Two: The Baltimore Stevedore } \\
\text { Union }\end{array}$ \\
\hline Symbolic Interactionism & $\begin{array}{l}\text { Primarily focuses on relationships between } \\
\text { people that are rooted in the exchange of } \\
\text { meaning through language and shared symbols } \\
\text { that help people make sense of their world. }\end{array}$ & $\begin{array}{l}\text { Season Four: Namond's Family } \\
\text { Changes }\end{array}$ \\
\hline Social Construction & $\begin{array}{l}\text { Suggests that reality is what society collectively } \\
\text { assembles it to be. That there are shared } \\
\text { meanings that are enduring and are generally } \\
\text { accepted in society. }\end{array}$ & $\begin{array}{l}\text { Season Three: Hamsterdam } \\
\text { Season Five: Red Ribbon Serial Killer }\end{array}$ \\
\hline Conflict Theory & $\begin{array}{l}\text { Purports that society is made up of different } \\
\text { segments that are in competition with one } \\
\text { another for resources including and institutions } \\
\text { perpetuate a system of inequality which } \\
\text { maintains an unequal power structure. }\end{array}$ & $\begin{array}{l}\text { Season Five: Hamsterdam } \\
\text { Season One: The Chess Lesson }\end{array}$ \\
\hline
\end{tabular}

Table. 1 to be Cont......... 


\begin{tabular}{|l|l|l|}
\hline Rational Choice Theory & $\begin{array}{l}\text { This theory suggests that actors } \\
\text { make selections for outcomes }\end{array}$ & $\begin{array}{l}\text { Season Three: Cutty opens a gym } \\
\text { Season Four \& Five: Caretti and the } \\
\text { based on personal preferences that } \\
\text { demonstrate internal consistency } \\
\text { Baltimore City Public Schools }\end{array}$ \\
$\begin{array}{l}\text { over time and seek to enhance } \\
\text { outcomes. }\end{array}$ & \\
\hline
\end{tabular}

\section{Theory Definitions and Examples Systems Theory}

Within the Social Work discipline, a system is a social entity characterized by individuals or other social units possessing functionally interdependent relationships (e.g. a family, organization, or community) [7]. Systems perspective is an approach that sees human behavior as the outcome of reciprocal interactions of persons operating within organized and integrated social systems.

Social workers were drawn to systems perspective in the 1960s as they shifted from a psychiatric model of practice to a model more inclusive of the environment [16]. Drawn heavily on the work of sociologists Talcott Parsons [17] and Robert Merton [18], psychologist Uri Bronfenbrenner [19] and biologist Ludwig Von Bertalanffy [20], systems perspective was influenced by functionalism, in which social systems are thought to be orderly and remain in a relatively stable state known as homeostasis [21]. Each part of a system serves an essential function in maintaining the system and the functions of the various parts are coordinated to produce a well-functioning whole and are adapted to the context of their environments, achieve their aims, and provide for their component sub-systems [22].

Social systems are dynamic, ever changing, and evolving. In systems perspective, it is essential to anticipate the complex relationships between system elements and the consequences that follow when any part of the system is changed [21]. The dynamics of social systems occur within an articulated structure. Structure defines the fixed elements in a system demarcated by boundaries that distinguish the external limits that identify a social system [7]. Boundaries serve to maintain roles and rules that provide system stability.

Systems operate interconnectedly and on various levels. A suprasystem is the specific social context within which the system functions [23]. It corresponds to the social environment, is always composed of specific external social systems that influences, and is influenced by, the focal or target system. The focal system is the subject of observation or intervention. Subsystems are component elements of the focal system.

Social work is unique in its mission to both address the personal and societal aspects of social problems, and social systems theory aids the social worker in formulating intervention goals at both levels. To examine parts of a system that interconnect and interact to make a complete whole [24], we can look at Avon Barksdale who is the primary target during the first season of The Wire, and the Barksdale drug organization crisis during season two.

Barksdale's drug organization is a readily available example of a system. The organization has clear geographic boundaries in West Baltimore, which includes Franklin Terrace Towers housing project (i.e., The High Rises), highly coveted prime real estate in terms of drug dealing territory. The interactions of the Barksdale organization and the police are exemplary of the interdependent relationships of systems theory. The Barksdale organization is largely stable, even maintaining prominence in spite of changes in leadership (i.e. the arrest of D'Angelo, the nephew of the King Pin, Avon Barksdale), with a clear hierarchy and functions that demonstrate the default mode of a system to seek homeostasis. As the police learn more about Avon Barksdale and his organization, Avon and his lieutenant and friend, Stringer Bell, modify behaviors of the organization to maintain order and homeostasis. Each part of the system (e.g., the package deliveries, the sales in the high rises, the maintenance of the pit, the methods of distribution, etc.) are all connected to keep the organization running smoothly. Elucidating the ways in which police brutality; confidential informants; changes in drug product impact the operations of the organization; and create the context in which to discuss the impact of one subsystem's behaviors or processes impact the options and behaviors of the larger system (i.e.., the Barksdale organization).

Another example of systems theory also comes from season two with the storyline of the blue-collar working class in the Baltimore port. The dock-workers and stevedores from the Baltimore Harbor struggle to make ends meet because the shipping industry has largely bypassed the port of Baltimore in order to avoid increased operational costs added by the unions. Union leader, Frank Sobotka, under economic pressure to provide for his un-and under-employed members, creates a quid pro quo smuggling system of manipulating shipping records to "lose" certain shipping containers.

This external arrangement with a businessman known as "the Greek" creates a reciprocal relationship in which "the Greek" pays Sobatka for manipulating the shipping manifests. The Greek uses the contents of the lost containers for his business in the black market, while Frank is able to funnel these monies to pay his union members. When one of those lost containers is left on the dock, the dock police, representing a supra system, discovers dead female victims of human trafficking from Eastern Europe, thus beginning the plot of the "girls in a can" and irrevocably changing the interconnecting boundaries of the dock system with other suprasystems including the FBI, the Baltimore Police, and drug organizations.

This example illustrates how systems theory can be influenced by the inequities of capitalist systems. World systems theory [25] claims that resource-rich systems exploit poor peripheral systems. This is evident in the imbalanced relationship between a desperate Sobatka and the well-resourced and connected Greek. In this example, we can see the demand of sex workers as a reflection of global inequality when the supply comes from economically disenfranchised societies to meet the demand in more powerful systems.

It is worth noting here that one can view the entire milieu of the series from a systems perspective. Using that framework, Baltimore is the focal system with each season demonstrating interconnected sub-and supra-systems. Examples of correlated systems are the Barksdale and Stansfield drug organizations, the Baltimore police department, the wiretap detail, the stevedores, and politicians. Each of these systems has myriad sub-systems that often interact and conflict with one another. Supra-systems within which these systems and sub-systems operate include criminal justice, human trafficking, poverty, racism, capitalism, government, the media, and education. Further, the longitudinal aspect of the series over five seasons highlights the interconnectedness and complexity of each of the themes of the series. These themes are presented as an interwoven tapestry that unwinds throughout the series. Like social work practice environments, the intended and unintended consequences of policy and personal decisions are revealed. 


\section{Symbolic Interactionism}

Symbolic interactionism is a theoretical perspective focusing on the nature of interaction, the dynamic of social activities taking place between persons [26]. This perspective addresses the interactions between the individual and society and is concerned with symbolic communication such as gestures and language. A major purpose of this theory is to examine the process by which the naïve individual becomes a functioning member of society - a person becomes fully human only by the continuous process of interactions between the person and the social environment. Mead [27] and Cooley [28] emphasized the importance of society in shaping the individual's personality and sense of self, stressing the centrality of languagelanguage consisting of shared symbols by which individuals learn to interpret events and communicate their understanding with others. Symbols are agreed upon representations of something else [26], and have meaning to both the user and to others with whom the user communicates [27].

The self as a social object begins in childhood through interaction with parents and others. Symbolic interactionism suggests that as the child develops an understanding of social expectations, these are internalized into the emerging self [29]. The sense of self that emerges in this process is distinctive to symbolic interaction. The self is a reflexive process rather than a fixed structure [27]. "I" and "Me" are essential aspects of self that are necessary for reflexive process to occur [29]. "I" is the active, spontaneous aspect of self- the I acts and then observes the reactions of others - the reactions of others are then internalized. "Me" is developed over time and is composed of internalized, organized perceptions of the attitudes of others [30].

Human consciousness and the sense of self is shaped by continual social interaction, which creates a social reality based on social interactions and the development of common understanding of the world $[31,32]$. Social reality is created when people, in social interaction, develop a common understanding of their world. People perform for their social audiences, but they are also free, active, and creative. Social interaction is grounded in language customs, as well as cultural and historical contexts. People can modify meanings in the process of interaction. Society consists of social processes, not social structures.

The degree to which a person is well socialized depends on how accurately the generalized other model corresponds to the actual social reality. Throughout life, the self continues as both subject and object. By imagining the reactions of others, the self selects a role best suited to gain a desired end. Without the "I" there would be nothing unique about the individual. Without the "me", there would no responsibility for choices.

Symbolic communication is crucial to the clandestine operations of the Barksdale organization. Understanding those symbols or codes, is the linchpin to the police detail's wiretap that begins in season one and is the namesake of the show. With emphasis on shared language of symbols, the Barksdale organization creates messages consisting of seven-digit phone numbers with two-digit tags. This symbolic communication allows the organization to run its operations without detection from outsiders. It is only when wiretap detail Detectives Freemon and Prysbylewski crack the number swapping codes on the wiretap, that they are able to interpret the meaning of esoteric language of the organization. The detail uses the code interpretations to capture soldiers such as Bodie, D'Angelo, and Poot in the process of selling drugs. The detail's newfound understanding of the complexity of designed communication patterns facilitates their ability to make arrests and put pressure on the Barksdales.

An additional example occurs in season four when we see the influence of symbolic interaction in the conflicting relationships between Namond's family of origin and the mentorship provided by Bunny Colvin. Namond is what is termed a "hopper" one of the young male children who are engaged with "the game." The common reality of Namond's world in west Baltimore is participating in the Barksdale organization, which is modeled by his father Wee-Bay, one of the most trusted soldiers in the organization. When Wee-Bay goes to prison on a life sentence, Namond's mother expects him to share her common understanding of being part of the organization and follow in his father's footsteps. She reinforces the expectation of him to "be a man" and provide for the family the same way his father did. Namond reluctantly enters into this defined reality by joining Bodie's corner crew. This represents Namond's conflict with "me" development. Within the reality of participation in the drug organization (i.e., "the game"), Namond struggles to conform to the established rituals and expectations of corner work, by bristling at the order to pull back his long hair in order to be less conspicuous to police. This example depicts Namond's cognitive dissonance between "I" and "me".

Namond is also presented with a contrasting reality through his participation in a research project in his middle school co-facilitated by Bunny Colvin. Bunny demonstrates a different reality provided by education, away from interaction in "the game." This is demarcated by the contexts of school, family, and development as an adolescent. Ultimately, with encouragement from his father to embrace social change and opportunity for new roles away from "the game," Namond accepts Bunny's offer of a paradigm shift by moving in with his family, leaving the expected reality of his biological parents and the Barksdale organization.

\section{Social Construction}

Similar to symbolic interactionism, social construction addresses shared meanings. Social construction, a theory largely associated with the postmodern era, is essentially a way to come to terms with reality. It is initially rooted in the work of Thomas Kuhn's [33] paradigm shift and the seminal work on the topic by Berger and Luckmann [34]. The focus of the social constructionist perspective is that individuals determine what is right and true based on language, interactions and collective societal determinations, which determine how they interpret the world and their place in it [7]. Humans are social beings who interact with others and their physical contexts, developing shared meanings about the world. In this perspective, there is no singular objective reality, but rather shared subjective realities [27, 28]. Knowledge is something that is constructed rather than an objective reality. Individuals or groups of individuals, particularly by powerful social agents or "claim-makers" [35] define reality [36], and knowledge is created through the interactions of individuals in society [34]. Young and Colin purport that social constructivism focuses on the collective constructions of world experiences through cognitive processes. Individuals or groups of individuals define reality [36], knowledge is created through the interactions of individuals in society [34].

To this end, social problems and their targets are socially constructed [37]. Loseke [38] asserts that social circumstances are not a problem until they are defined as such by "claims-makers" [35]. From this assertion other constructionist theories emerge. Within the social construction framework and particularly relevant to urban settings is the controversial "Broken Windows" theory of urban decline promoted by scholars Wilson and Kelling [39]. This theory posits that "minor forms of public disorder lead to serious crime and a downward spiral of urban decay (p.319)" [40]. This framework is the premise behind the commonly heard statement "there goes the neighborhood." Thereby purporting that at the appearance of observed disorder and perceived negative community or neighborhood occurrences the decline of a neighborhood is inevitable.

The premise is similar to that of the perceived phenomenon of "white flight" [41] and "brain drain" [42]. Meaning, that undesirable activities such as loitering and public drinking begin in a neighborhood beget physical undesirability such as vacant lots 
defined by Welsh, Braga, \& Bruinsma [44] create fear in residents (p. 448). This fear is then the impetus for those who have the means to leave the area, thereby leaving the most vulnerable as the only community inhabitants.

The visual decline of the neighborhood suggests that residents do not value their property or the environment and are indifferent to the plight of the neighborhood. As such, bad actors and criminal activity fester due to the perceived indifference of the neighborhood residents. The broken windows theory suggests that a broken window will signal the decline of the neighborhood and encourage the spread of more serious disorder and ultimately crime of various severity $[44,45]$.

Whether absolute truth or not, the idea or concept is constructed by the collective society and is maintained within the society [46]. These shared understandings become the truth or reality within the social construct of that microcosm. Social construction requires a shared implicit and often explicit agreement on the meanings and value of a concept [35]. It suggests that the only value of a concept is what the collective bestows upon it and it is at the same time malleable and fixed so that as society's values and perceptions change or are reinforced, so do our realities [7].

As such, the way in which problems and issues become defined is a critically important aspect of policy development. The problems addressed by social policy are constructed from a mixture of economic, social, and political circumstances as well as values, ideologies, and attitudes, rather than empirical analyses. As this mixture evolves and changes, the prescribed solutions have fluctuated over time [37]. These solutions ultimately reflect the values of the public toward caring, sharing, and collective action through public policy. There is a political dimension to the social construction of social policy in that the conceptualizations of social problems are generally designed to serve the interests of those who define the problem or issue [47].

Two examples of social construction that are demonstrated in The Wire include Hamsterdam and the serial killer of season five of The Wire. Hamsterdam is introduced in The Wire in the fourth episode of the third season of the series. Hamsterdam, an eponym of the name of Amsterdam, the capital of the Netherlands where decriminalization of drugs is widely embraced, and the imagery of hamsters running on a wheel. In a decaying West Baltimore area, Hamsterdam is a social experiment created by police chief Bunny Colvin. Hamsterdam is a geographic area where drugs can be sold and used without police retribution. The area is designed to keep drugs and other related crime from spilling out into other areas of the city.

The premise is that if drugs and their attendant issues are confined to this limited geographic area, other areas of the city would be safe and free of the crime, drug deals, drug use, and violence that comes with "the game." The Mayor and the Police Department brass have defined the drug problem in Baltimore by the homicides, or "bodies" that accumulate as a result of contested drug territory. The statistics of the murders that are largely due to conflicts between rival drug organizations is the socially constructed problem. So much so that drug organizations hide dead bodies in "the vacants" (i.e., boarded up vacant houses in the city) to eliminate them from reaching the homicide desk and thereby reducing the city's murder rate.

While it has been decried that the existence of Hamsterdam is unrealistic as part of the series, it does exemplify social construction. The existence of Hamsterdam flips the normal and expected relationship between the police, drug dealers, and the community on its head. Hamsterdam, in essence, legalizes drugs, provides a safe space for the sale and use of drugs in the open without the harassment or arrest by police. While some of the police are reluctant to adhere to these new norms, they abide by them because this social experiment has been initiated by the then police chief.

This experiment also allows for coalitions and collaborations to occur that are otherwise impossible due to the criminalization of drugs.
Public health agencies are able to establish condom distribution and needle exchange to promote safer behaviors. Organizations are able to engage in direct outreach for substance abuse treatment, all within a policy-sanctioned public area.

The creation of Hamsterdam creates, or constructs, a reality where the social problem of drugs and drug sales is not inherently problematic. Instead, it defines the problem as the death and destruction created by the conflicting drug organizations. In fact, the violence perpetrated as part of "the game", and increasing murder rate from rival organizations, are the social problem. However, it magnifies and emphasizes the drug problem for residents of the city. Creating a concentrated space for the dealing and consumption of illicit drugs does not address issues of substance use in the community, but it does solve the problem of the increasing murder rate of the city.

Similarly, in its incredulity but exemplary of social construction, is season five of The Wire. The entire season focuses on the development of a "fake news" story. In season five, we refocus on James McNulty's story line. McNulty is a severely flawed but good-hearted and strategic police who cannot seem to stay out of trouble. In McNulty's desire to reignite attention to the needs of the ailing police department, he creates an elaborate scheme about a serial killer targeting homeless men by planting false evidence on corpses to create a non-existent connection between the deaths. Not only does this story attract the attention of the mainstream local newspaper (The Baltimore Sun), it is capitalized by the embattled Mayor Carcetti in his reelection, and garners much needed resources for the Baltimore City Police Department.

Much of what holds the story together is the meaning associated with a red ribbon which is tied to the limbs of several bodies that enter the morgue. Through a series of conversations with a local reporter, McNulty literally constructs a meaning for the red ribbon that serves as the signature of a non-existent serial killer. While in season five the story falls apart, it is important to realize that the common understanding was initially embraced. The echo chamber that is created by the inaccurate stories fed to a reporter, who fails to fact check, perpetuates the belief that Baltimore has been plagued by a serial killer of homeless men.

\section{Conflict Theory}

Conflict theory asserts that there are struggles within a given society that arise as a result of inequity of resources, status, and power. This structural approach to conflict theory was first introduced by Karl Marx who theorized that the bourgeoisie class oppressed a larger, but less powerful, proletariat [48]. Marx suggested that the bourgeoisie (owners) held power due to their accumulation of resources and ownership status and oppressed the proletariat (working class and poor citizens) by the utilization of symbolic interactionism that operated in their favor. According to Marx, this conflict was solidified in the very fiber of society via the "superstructure" of society, made up of societal institutions such as political structures and culture.

These conflicts are essential to and inherent in any given society. Social change erupts when groups must jostle for positions of dominance. Conflict is experienced when power (or capital) and control is contested. Conflict theory highlights inequity, dominance, subjugation, and oppression in social life. It suggests that when power is unequal, dominant groups exert their will over others leading to a system where social order is based on this inequity and control of resources [49]. It also suggests that the bourgeoisie (or ruling class) can often operate without repercussion because they make laws and control law enforcement.

Social conflict theory suggests that the justice system is biased toward the needs of the wealthy and ruling class members and actively protects their interests. Further, conflict theory rests on the premise that interests of the controlling regime are at odds with that of the less dominant group. These conflicts are often the impetus for 
social change and interrupt periods of stagnation and inertia that are not productive for the entirety of the society.

The most striking example of conflict theory is the competition for drug territory between the Barksdale and Stanfield organizations. In season three, Bodie is relocated to another corner to sell product. He finds himself in the midst of a turf war by infringing on Marlo Stanfield's drug territory. The added complication of less than stellar product, coupled with brutal beatings sent as signals by the Stanfield organization to respect their physical boundaries. The conflict places Avon and Marlo at odds with, yet again, deadly consequences. While there are attempts to share power through a newly developed co-op for the local drug organizations, it is not successful because neither Avon nor Marlo buy into the idea. They each are determined to keep their hold on their respective territory, suppliers, and customers.

Initially unbeknownst to Avon, Stringer Bell fosters the Barksdale organization's alliance in the co-op but intentionally excludes Avon. This creates interpersonal conflict between the two friends/business partners, ultimately leading Avon to murder Stringer. Avon publicly blames Marlo for the murder, thus escalating the conflict between these two organizations. A deadly and wide-reaching street war ensues that the Barksdale organization ultimately loses due to Avon's conviction for parole violations, weapons, and drug crimes. As Avon is sentenced to prison, Marlo watches his nemesis be dethroned in the courtroom. With his major obstacle out of his way, Marlo is crowned as Baltimore City kingpin.

An additional example of conflict theory can be found in the plot as it relates to Hamsterdam. Instead of the typical brute approach of "knocking heads" as voiced by Herc, one of the original police in the wiretap detail returned to the beat, he and his colleagues are forced to come to terms with the new norm of no force. His colleague Carver eventually embraces the new procedures of community policing. This is evident when he exacts an unemployment tax on the drug dealers to pay for a basketball hoop for children who were previously used to sell drugs on corners, but are no longer needed when sales can happen out in the open without impunity. Ultimately, conflict returns, as the mayor and police chief learn about Hamsterdam, and shut it down with militarized resources and force.

Another, less dynamic but equally insightful, example is the lesson D'Angelo graphically teaches Wallace and Poot during a checkers game in season one. They are using chess pieces to play checkers because they are ignorant of the rules of chess. D'Angelo provides an insight into "the game" that exemplifies the conflicts that arise within an organization. D'Angelo eloquently details the expendable nature of the pawns (i.e., low level dealers like Wallace and Poot) for Avon and Stringer to keep and exert control. Although Avon and Stringer Bell are not part of the traditional bourgeoisie and ruling class, they hold that position in "the game." They pay off witnesses and take advantage of a skewed system that protects their interest (and family). This relatively brief scene describes in clear detail the hierarchy and consequences of conflict, which in this case is any attempt to move higher in the drug organization.

\section{Rational Choice Theory}

The basis of Rational Choice Theory is the belief that individuals are reasoning actors who weigh means and ends, costs and benefits, and from this data he/she makes a rational choice that will enhance her/his outcomes. Rational choice theory's roots are in traditional economic theory but has expanded to other disciplines such as criminology [50]; sociology [51] health promotion [52], family studies [53] and social work [54]. Social workers do not generally reflect on rational choice theory in its purest form but are "most familiar with the rational choice perspective as it is manifested in social exchange theory in sociology, rational choice models of organizations, public choice theory in political science, and the emerging social network theory". Pratt posits that there has been an evolution in the theory and "Although the theoretical emphasis on the cost-benefit calculus still is central to the rational choice framework, it has matured into a more comprehensive perspective that appreciates the complexity of the nature of criminal behavior" (p. 43). Scholars have broadened the understandings of human behavior within the context of discourse surrounding rational choice theory to note how individual perceptions of the relative costs and benefits as well as contextual and environmental factors impact the decision to act.

The theory is largely based on the "expected utility" principle. Expected utility is thought to be a significant contribution to the ways in which individuals make decisions. This principle is a normative theory in that it describes how people should make rather than do make decisions. Expected utility weighs the probability of a desired outcome based on a particular act [55]. The principle suggests that the chosen course of action will be the act that has the highest probability of producing the desired outcome, or the closest to it [52]. Inherent in this framework is the reliance on a cost (or losses) benefit (or profit) analysis of the act versus the outcome [51]. The goal is to increase the desired outcome with the least cost at the highest benefit.

The basic assumptions of the rational choice theory are multifaceted. Keel [56] suggests that the fundamental assumptions of the theory are that individuals are rational beings; rationality is calculated; individuals have free will; individuals will act to maximize profit or benefits; when the choice is given, individuals will work to maximize self-interests; choices are determined by the potential consequences of an act and whether it is judged to be in violation of the social good, the social contract; governance structures are in place to maintain the social contract of society; and "swiftness, severity, and certainty of punishment are the key elements in understanding a law's ability to control human behavior" [56].

Embedded in rational choice theory is social exchange theory. Social Exchange Theory suggests social behavior is based on the desire to maximize benefits and minimize costs. The belief is that people weigh benefits and rewards of social relationships against the probability of risks and costs (Hutchison \& Charlesworth, 2010). When the risk outweighs the potential benefits, people will end the relationship or terminate the exchange. This framework acknowledges that exchanges will not always be equal and may provide temporary inequity in costs. However, a sustained imbalance of rewards versus costs will make the actor end the exchange. Social exchange theory also acknowledges that there may be differences in the level of resources in the exchange. Persons with greater resources in a social exchange hold what is often unacknowledged power over other actors in the exchange. Social exchange theory contributes to the understanding of rational choice theory as a means for individuals to seek an advantage for themselves.

Rational choice literature suggests that individuals operate in ways that will increase positive outcomes and avoid unpleasant circumstances in their decision making [57]. Studies have shown that criminals often do not think about the negative consequences of their behaviors but instead focus on the profits and benefits of the act [58]. In general, rational choice theorists do not assume that all acts are committed with full knowledge, free will, unlimited constraints, and tangible benefits.

Many of the influences on the rationality of decision making are not readily incorporated into a simple cost/benefit equation [51]. While most theorists agree that rational choice theory, in its purest sense, is not adequate to explain human behavior and that multiple mediating factors influence decision making. However, it may be explored as a portion of the thought process for agent actions.

Rational choice theory in The Wire is exemplified in the difficult and self-serving decisions made by Mayor Carcetti in regard to the $\$ 52$ million dollar deficit of the Baltimore City Public School System. Carcetti learns of this significant deficit only after he is elected as mayor. In an effort to fill the funding gap, he must make a request to the Governor of Maryland, who is willing to provide it, at the expense 
of Carcetti's own gubernatorial campaign ambitions. Carcetti, instead of accepting the funds and publicly acknowledging their source, rejects the governor's offer in order to help his own political ambitions. While this decision significantly hinders the operating budget for the City of Baltimore and makes his tenure as Mayor contentious and fraught with controversy within city government, it ultimately pays off in that Carcetti is elected governor of Maryland in season five.

Returning to the Barksdale organization after serving a 14-year prison sentence, Dennis Wise, aka Cutty, is quickly reinitiated back into the "game", earning respect for his experience, intelligence and muscle as an enforcer. When Cutty and his younger associates apprehend a thief from inside the organization, Cutty is horrified when they nearly kill the culprit rather than sending him a warning and allowing him to continue to work. Nevertheless, he continues his work until a turf war with rival drug dealer Marlo Stanfield results in a confrontation in which Cutty freezes.

It is then that he resigns from the organization, still with the respect of Avon Barksdale and others in "the game." We see Cutty operating under the expected utility principle of rational choice theory by deciding he wants to live and improve the lives of the younger generation in his community. Cutty taps into his skills as a boxer, and with the support and resources of the Deacon, he is able to start a gym to teach boxing to adolescents as an alternative to joining "the game".

\section{Conclusion}

This article provides a discussion of theoretical frameworks commonly used in social work. Using examples from The Wire, traditional HBSE conceptual frameworks and theories are discussed. Specifically, the first three CSWE Competencies are readily exemplified. While we would like to think that all aspects of social work are interesting and relevant, students may not think so. Traditionally, social work students do not readily see the relevance of research or theory in their educational experience due to the very practice-oriented nature of social work as a discipline [59].

A course using The Wire can be a rewarding experience for both students and instructors through mutual engagement [60]. In the words of a former student "What could be more fun than watching television and learning at the same time?" That is exactly the "selling point" of teaching a class using The Wire. Many students enroll in the class because they are excited about the television series. Either they have heard about the show, seen a few episodes, or have binged watched it and are fanatics. The television show is the hook. The well-designed course is the anchor.

In this article, we outline the examples instructors can use to crystalize the sometimes vague and nebulous theories used to guide social work practice. These examples and The Wire as a teaching tool is extremely relevant in 2020. During the time of a nationwide pandemic that has highlighted the interconnectedness of the economy and people's daily lives, and the social unrest that exploded at the murder of George Floyd by the police, The Wire proves to be an apropos tool for teaching human behavior in the social environment. Theories of human behavior help us frame the current context a bit differently and through a slightly different frame/lens.

As we look at the responses of workers, employers, protestors, and citizens, their responses may not seem logical or may appear to be irrational without a conscious examination. Upon further reflection and perhaps using an alternate paradigm, it may be that these behaviors in fact fit well into social theories and therefore are based on the context and milieu through which they are viewed. From this vantage, social work students may be able to engage in developing empathy, awareness, and ultimately multidimensional responses to social problems in practice.

While it is not addressed explicitly in this article, police brutality and the resulting protests are salient themes in The Wire. In the spring of 2020 protest and unrest erupted literally around the world, sparked by the murders of George Floyd, Ahmaud Arbery, and Breonna Taylor. These injustices, all too common in communities of color, highlighted issues of police brutality, racial profiling, poverty, social inequity, and a host of urban problems that are chronicled in The Wire. George Floyd's murder especially illuminated the unfair treatment of people of color at the hands of police. The unrest, seen on televisions across America, was a result of the frustration of citizens over social and economic injustice and brought these issues to the forefront of the national discourse and made The Wire all the more relevant.

This point in America's history, coupled with other incidents of police brutality and social injustice across the country, is an opportunity for instructors to look at inequity and racial discrimination, racism, and its history with renewed focus. Not only can instructors point to the vivid images real life to elucidate police brutality, they can also discuss the ways in which police officers approach their jobs as a soldier fighting against the community rather than a citizen of the community they serve. This is demonstrated precisely in the raid and "crack heads" or the inclination and circumstances in which Daniels encouraged a cover up of Officer "Prez" Pryzbylewski pistolwhipping a teenage boy by in season one. Or, the motivation for the brutality of Officer Walker as he breaks Donut's fingers in season four to exemplify issues of over policing and brutality.

Instructors can help students explore the underlying issues of urban communities by unpacking the circumstances and events that precipitated these events. The use of theories of human behavior to investigate these life mirroring events provides the opening for discussion of the current context within a safe space and environment. The experiential, guided examination of television characters, rather than the lived experience of students themselves, allows more openminded perspective development and interpretation/application of theories. As students apply the theories highlighted in this article, they will develop the perspective of self with others through familiarization with characters in their environments [60]. Perhaps students' insights into urban life through explicit exploration of the reciprocal influences between characters in the context of The Wire will inform students' capacity for empathy and empowerment in their client-worker relationships.

In an economic and social environment of intolerance, economic bifurcation, police brutality and redacting of the social safety net, it is imperative that social work students have an awareness of the complexity of human behavior within the context of social problems for effective social work practice. The use of The Wire can create rich learning opportunities in which students dispel stereotypes and reconsider their knowledge of the urban experience. The current climate of society requires social work students to develop discerning critical thinking skills [61]. We argue that The Wire, through its complex situations and deeply developed characters, can facilitate students' practice of reasoned judgment, empathy, and curiosity which can translate into competent social work practice at this historical time.

Acknowledgments: Special thanks to Dr. Quinetta Roberson and Mr. Jesse Longacre for their thorough comments on the drafts of this manuscript. Thank you to the peer reviewers for their thoughtful comments and feedback.

Conflict of interests: The authors declare no conflict of interest.

\section{References}

1. Council on Social Work Education Commission on Accreditation (2016) EPAS Handbook. Council on Social Work Education, Washington, DC.

2. Center for Sustainable Systems, University of Michigan. 2019. "U.S. Cities Factsheet." Pub. No. CSS09-06 http://css.umich. edu/sites/default/files/US\%20Cities_CSS09-06_e2019.pdf 
3. Pew Research Center, May 2018, "What Unites and Divides Urban, Suburban and Rural Communities"

4. Delgado, M. (2000). Community social work practice in an urban context. Oxford: Oxford University Press.

5. Germain, C. B. (1991). Human behavior and the social environment: An ecological view. New York: Columbia University Press.

6. Schriver, J. M. (2011). Human behavior and the social environment: Shifting paradigms in essential knowledge for social work practice. New York City: Pearson.

7. Payne, M. (2005). Modern Social Work Theory (3rd ed.). Chicago: Lyceum.

8. Gaynor, T., \& Taliaferro, J. (2016). Teaching The Wire: Frameworks, Theories and Strategies for the Classroom. Jefferson: McFarland.

9. Moore, A. (2011). Teaching HBO's The Wire. Transformative Dialogues: Teaching \& Learning Journal, 5(1), 1-14. Retrieved from https://www.kpu.ca/sites/default/files/Teaching\%20 and\%20Learning/TD.5.1.9_Moore_eaching_The_Wire.pdf

10. Entertainment Weekly, Bullseye. June, 2020

11. Bennett, D. (2010). This will be on the midterm. You feel me? Slate. March 24, 2010

12. Moore, A. (2011). Teaching HBO's The Wire. Transformative Dialogues: Teaching \& Learning Journal, 5(1), 1-14. Retrieved from https://www.kpu.ca/sites/default/files/Teaching\%20 and\%20Learning/TD.5.1.9_Moore_Teaching_The_Wire.pdf

13. Mittell, J. (2012). "The Wire in the Context of American Television," In L. Kennedy \& S. Shapiro, The Wire: Race, Class, and Genre, (pp. 15-32). Ann Arbor: University of Michigan Press.

14. Taylor, R. and Eidson, J., 2012. "The Wire," William Julius Wilson, and the Three Sobotkas: Conceptually Integrating "Season 2: The Port" into a Macro-Level Undergraduate Communities and Crime Course. Journal of Criminal Justice Education, 23(3), pp.257-282.

15. Trier, J. (2010). Representations of Education in HBO's The Wire, Season 4. Teacher Education Quarterly, 37(2), 179-200. Retrieved June 10, 2020, from www.jstor.org/stable/23479595

16. Beresford, P. (2005). Social work and a social model of madness and distress. Social Work and Social Sciences Review, 12(2), 5973. https//doi: 10.1921/17466105.12.2.59

17. Parsons, T. (1972). Culture and social system revisited. Social science quarterly, (53)2, pp. 253 -266.

18. Merton, R. (1968). Social theory and social structure. New York: The Free Press.

19. Bronfenbrenner, U. (1979). The ecology of human development: Experiments by nature and design. Cambridge: Harvard University Press.

20. von Bertalanffy, L. (1933). Modern theories of development. London: Oxford University.

21. Leighninger, R. (1977). Systems Theory and Social Work: A Reexamination. Journal of Education for Social Work, 13(3), 44-49. Retrieved June 9, 2020, from www.jstor.org/ stable/23038730

22. Kihlström, A. (2011). Luhmann's system theory in social work: Criticism and reflections. Journal of Social Work, 12(3), 287299. https//doi: 10.1177/1468017310386425

23. Luhmann, N. (1990). Essays on self-reference. New York: Columbia University Press.

24. Teater, B. (2015). International Encyclopedia of the Social \& Behavioral Science, 2nd ed. New York: Elsevier.
25. Chirot, D. (2015). International Encyclopedia of the Social \& Behavioral Sciences, 2nd ed.

26. Charón, J. (1979). Symbolic interactionism. Englewood Cliffs, NJ: Prentice Hall.

27. Mead, George Herbert. (1934). Mind, Self, and Society Chicago: University of Chicago Press.

28. Cooley, C.H. (1964) Human nature and the social order. Schocken, New York.

29. Rock, P. (1979). The making of social interactionism. London: MacMillian Press.

30. Shibutani, T. (1955). Reference groups as perspectives. American journal of sociology. (60). pp.562 - 569.

31. Gans, H. (2006). The war against the poor. New York: Basic Books.

32. Hutchison, E. D., Matto, H. C., Harrigan, M. P., Charlesworth, L. W., \& Viggiani, P. A. (2007). A multidimensional working model for social workers: Challenges of living. Los Angeles: Sage Publications.

33. Kuhn, T. (1962). The structure of scientific revolutions. Chicago, IL: Chicago University Press.

34. Berger, P. L. \& Luckmann, T. (1991). The social construction of reality: A treatise in the sociology of knowledge. New York: Penguin.

35. Michailakis, D., \& Schirmer, W. (2014). Social work and social problems: A contribution from systems theory and constructionism. International Journal of Social Welfare, 23(4), 431-442. https//doi: 10.1111/ijsw.12091

36. Steedman, P. (2000). On the relations between seeing, interpreting and knowing. In Steier, F. (Ed.), Research and Reflexivity, (pp. 53-62). London: Sage.

37. Schneider, A., \& Ingram, H. (1993). Social Construction of Target Populations: Implications for Politics and Policy. American Political Science Review, 87(2), 334-347. https// doi:10.2307/2939044

38. Loseke, D. (2003). Thinking About Social Problems. Hawthorne, NY: Aldine Transaction.

39. Wilson, James Q., Kelling, George L. 1982. "Broken Windows: The Police and Neighborhood Safety." Atlantic Monthly 211:29-38

40. Sampson, R. J., \& Raudenbush, S. W. (2004). Seeing Disorder: Neighborhood Stigma and the Social Construction of "Broken Windows." Social Psychology Quarterly, 67(4), 319-342. https://doi.org/10.1177/019027250406700401

41. Jego, C., \& Roehner, B. (2006). White Flight or Flight from Poverty?. Journal of Economic Interaction And Coordination, 1(1), 75-87. https//doi: 10.1007/s11403-006-0004-9

42. Renn, A. (2015). Brain Gain in America's Shrinking Cities. New York: Center for State and Local Leadership at the Manhattan Institute. Retrieved from https://media4.manhattaninstitute org/ $\mathrm{pdf} / \mathrm{cr}$ _102.pdf

43. Boggess, L., \& Maskaly, J. (2014). The spatial context of the disorder-crime relationship in a study of Reno neighborhoods. Social Science Research, 43, 168-183. https//doi: 10.1016/j. ssresearch.2013.10.002

44. Welsh, B. C., Braga, A. A., \& Bruinsma, G. J. N. (2015). Reimagining Broken Windows: From Theory to Policy. Journal of Research in Crime and Delinquency, 52(4), 447-463. https:// doi.org/10.1177/0022427815581399

45. Ortigueira-Sánchez, L. (2016). Influencing factors on citizen safety perception: systems and broken windows theories. International Review on Public And Nonprofit Marketing, 14(1), 95-111. https//doi: 10.1007/s12208-016-0163-x 
46. Gaynor Harris, S. R. (2006). Social Constructionism and Social Inequality: An Introduction to a Special Issue of JCE. Journal of Contemporary Ethnography, 35(3), 223-235. https://doi. org/10.1177/0891241606286816

47. Handler, J., \& Hasenfeld, Y. (1991). The moral construction of poverty. Newbury Park: Sage Publications.

48. Marx, K., Engels, F., Engels, F., \& Wood, E. (1998). The Communist manifesto. New York: Monthly Review Press.

49. Oko, J. (2012). Understanding and Using Theory in Social Work (Transforming Social Work Practice Series) (2nd ed.). Newbury Park, CA: Learning Matters.

50. Gul, S. K. (2009). An evaluation of the rational choice theory in criminology. Journal of sociology and applied sciences, 4(8), pp. $36-44$.

51. Akers, R. L. \& Sellers, C. S. (2013). Criminological Theories: Introduction, evaluation, and application. New York: Oxford University Press.

52. Djulbegovic, B., Elqayam, S., \& Dale, W. (2018). Rational decision making in medicine: Implications for overuse and underuse. Journal of evaluation in clinical practice, 24(3), 655665. https://doi.org/10.1111/jep.12851

53. White, J. M. (2005). Advancing family theories. Thousand Oaks, CA: Sage Publications, Inc.

54. Coleman, J. S. (2009). Individual interests and collective action: Studies in rationality and social change. Cambridge: Cambridge University Press.
55. Mongin, P. (1997) Expected utility theory. In (J.Davis, W.Hands, and U.Maki, (Eds.), Handbook of economic methodology (pp. 342-350). London: Edward Elgar.

56. Keel R. (2019, November 26). Rational Choice and Deterrence Theory. http://www.umsl.edu/ rkeel/200/ratchoc.html

57. Hayward, K. (2007). Situational crime prevention and its discontents: Rational choice theory versus the 'Culture of now'. Social Policy \& Administration, 41(3), 232-250. https// doi:10.1111/j.1467-9515.2007.00550.x

58. Pease, K. (2006), Rational choice theory. In E. McLaughlin and J. Muncie, The Sage Dictionary of Criminology, London: Sage.

59. Taliaferro, J. D., \& Ames, N. (2010). Implementing an elective BSW community-based evaluation research course. Journal of Baccalaureate Social Work, 15(1), 105-119.

60. Edwards, J. B. \& Richards (2002). Relational teaching: A view of relational teaching in social work education. Journal of teaching in social work (22)1 - 2, pp. 33 - 48.

61. Gibbons, J. \& Gray, M. (2002). Critical thinking as integral to social work practice. Journal of teaching in social work, (24)1 -2 , pp. 19 - 38. 